\title{
A francia-német tandem és Európa jövője
}

\section{The Franco-German Tandem and the Future of Europe}

\section{Zachar Péter Kriszlián \\ https://doi.org/10.47707/Kulugvi_Szemle.2021.4.3}

Összefoglaló: A jelen tanulmányban a francia-német együttmúködés aktuális fejlődésének néhány mozzanatát igyekszem megvilágítani, különös tekintettel a 2017 óta, azaz Macron elnök és Merkel kancellár időszakában meghirdetett új javaslatokra. A jelenleg formálódó új német kormány ugyanis számos tekintetben már uniós célként határozza meg az aacheni szerződésben foglalt törekvéseket. A két ország viszonyának fejlődését történelmi szempontok alapján többször és mélyrehatóan elemezték. A második világháború befejezése óta, de fóleg az elmúlt évtizedekben, a kapcsolataikat mindig a jóakarat, az együttmúködés, a kölcsönös megértés és az Európa megújitását célzó kezdeményezés jellemezte. Ezért a viszonyrendszerük és annak az európai politikára gyakorolt hatása a nemzetközi kapcsolatok elméletében is visszhangra talált. A tanulmány igyekszik felvázolni, milyen javaslatokat és milyen motivációk mentén igyekeznek a felek az európai egység érdekében megfogalmazni. Továbbá, hogy mi vezet a föderációs elképzelések erősödése irányába, és miért kerülhet sor a különösen látványos változásra a német gazdaságpolitikai felfogásban, amely a helyreállítási alap létrehozása kapcsán volt tetten érhető. A munka során kiemelten igyekszem bemutatni: a közös fellépés célja mindkét partner pozícióinak a megerősítése, ugyanakkor a közösségen belüli domináns vezető szerep fenntartása.

Kulcsszavak: Emmanuel Macron, Angela Merkel, francia-német együttmú ködés, európai integráció

Abstract: In this paper, I will try to shed some light on the current development of Franco-German cooperation, with a particular focus on the new proposals announced under President Macron and Chancellor Merkel since 2017. In many respects, the new German government currently laking shape already defines the ambitions of the Treaty of Aachen as an EU objective. The development of Franco-German relations has been the subject of several in-depth historical analyses. In recent decades, since the end of the Second World War, these relations 
have ahways been characterized by goodwill, cooperation, mulual understanding and initiative for Europe. Therefore, the relationship between the two countries and its impact on European politics has also found an echo in the field of international relations theory. It is therefore extremely important to understand the proposals and molivations that the parties are trying to put forward in the interests of European unity. A particularly striking change in German economic policy can be observed in the conception of the new recovery fund. In the course of this work, particular attention will be paid to the fact that the aim of joint action is to strengthen the positions of both partners while maintaining a dominant leadership role within the Communily.

Keywords: Franco-German cooperation, Emmanuel Macron, Angela Merkel, European integration

\section{Bevezetés}

Franciaországnak és Németországnak az európai integráció keretei között folytatott több évtizedes együttmúködése a diplomáciatörténet, a nemzetközi kapcsolatok és a (poszt)bipoláris világrend tanulmányozása szempontjából is jól kutatott és különösen fontos téma. Tör téneti távlatokban az egymáshoz való viszony koordinátáit a francia külpolitikában mindvégig két egymással versengő irányzat jellemezte, amelyek eltérő hangsúlyokat igyekeztek behozni az európai politikába: egyfelől a nagyhatalmi pozíció, másfelől az egyes területeken elmélyített kooperáció révén kialakítandó francia biztonság politikája, amelyek egymást váltó korszakokat rajzoltak ki a külüigyi kormányzás tekintetében. Mindkettőt alkalmazták már a két világháború közötti időszakban is (Diószegi, 1994, 268-296. o.), és a második világháború nyomán a velük kapcsolatos vita ismét kiélesedett.

A hidegháború megjelenésével, a gyarmatokon mutatkozó térvesz téssel és súlyos problémákkal, valamint a francia globális politika visz szaszorulásával kéz a kézben járt egy egyértelmú fordulat: az 1950-es évek elejétől Párizs az európai integráció keretében a nagyhatalmi gloire-ról az együttmúködés securité politikájára váltott (Rieker, 2017). Ennek eredményeként az újonnan megalakult (nyugat)német állammal 


\section{Külïgyi Szemle}

közösen - több egymást követő hullámban - megteremtették az eu rópai integráció alapelemeit és mélyebb kapcsolódási pontjait. Ebben nemcsak a politika és a gazdaság, illetve - újabban - a védelmi politika és a fejlesztési segélyek szintje játszott fontos szerepet. A francia-német partnerség sajátossága az elmúlt évtizedekben a civil társadalom szintjén megvalósuló mélyreható egyuittmúködés volt, ami hozzájárult a lakosság szemléletváltásához, az örökös szembenállásról a szomszédos országgal való valódi barátságra történő áttéréshez (Lay és Nix, 2007; Zachar, 2018). A francia kormányzatok számára ettől kezdve az esetleges európai vezetô szerep csak a német politikával való együittmúködésben volt elképzelhető, és a nagyhatalmi pozíció elválaszthatatlanná vált a Rajna menti biztonságtól.

A francia világpolitikai törekvésekhez való időnkénti visszatérés - küiönösen Charles de Gaulle időszakában - sem lehetett más, mint az Európában elért biztonság és prosperitás francia vezetéssel történő kiterjesztése a globális politikára. Az univerzalista nemzeti nagyság (affirmation nationale, grandeur) elérése csak Európa egységén keresztül sikerülhetett. („Európa erős francia kontúrokkal.” Balázs, 2009.) Így az elmúlt évtizedekben - a politikai feszüiltségek és a néha eltérő megközelítések ellenére - mindig is a jó szándék, az együttmûködés, a kölcsönös megértés és az Európáért való kezdeményezés jellemezte a német-francia kapcsolatokat. Ennek eredményeként a két ország történelmi megbékélése, mindenkori bilaterális viszonya és annak az európai politikára gyakorolt hatása a nemzetközi kapcsolatok elméletében is komoly visszhangra talált (Nourry, 2012).

A francia-német együittmúködés közelmúltbeli fejlődésének jobb megértése érdekében érdemes az IR-elmélet egyes nagy iskoláit áttekinteni, hogy kiderüiljön, azok hogyan látják e duó fejlődését. Történelmileg a nemzetközi kapcsolatok első nagy iskolája az idealista felfogás volt, amely az első világháború után vált elméletként is világszerte ismertté. E liberális-ideális elmélet szerint az államok együttmúködése mindig sikeresebb, és stabilabb békefeltételekhez vezet, mint az ellentét vagy az ellenségeskedés. A liberális integrációs elmélet és az abból következő spill-over koncepció (Rosamond, 2000) segít megérteni, 
hogy az 1950-es évek óta miért múködik együtt ez a két állam egyre aktívabban és egyre több politikai területen. A neoinstitucionalisták számára ez egy koordinációs mechanizmusokkal és strukturált megállapodásokkal rendelkező kétoldalú rendszert jelent (Webber, 1999), míg ezt a rezsimelmélet a két kormány aktív lépéseit és elvárásait egyaránt befolyásoló formális és informális szabályok összességeként ismeri el (Cole, 2001).

A demokratikus békezónák modern elmélete a francia-német megbékélést a hosszú távú béke építésének folyamataként értelmezi. Ez az elmélet azt is megmagyarázza, hogy a két állam integrációja hogyan lett egyre összehangoltabb, amikor egy-egy kancellár és elnök mélyebben elkötelezte magát a demokratikus értékek, a nyitott társadalom és az erősen integrált gazdasági kapcsolatok mellett. Ez utóbbiak, a gazdasági összefonódások alapvető magyarázatul szolgálhatnak a neofunkcionalisták elméletében is, mert a két ország közötti gazdasági együttmúködésnek, majd más szakterületeknek is a különösen mély integráltságára mutatnak példát (Haas, 1964). Sőt, a gazdasági kérdések a klasszikus marxista elmélet és Immanuel Wallersteinnek a gazdasági világrendről alkotott felfogása tekintetében is a segítségüinkre vannak (Robinson, 2011). Ezen elméletek értelmében Németország és Franciaország modern kapitalista fejlődése természetesen új értékesítési piacokat és olcsó beszállítókat is keres, így érthető a két országnak a külkereskedelmi területeken folyó együttműködése és a szabad piacgazdaság értékeinek a világméretű képviselete.

A manapság elterjedt konstruktivizmus elmélete segít megérteni az elit eszmei változását, illetve azt, hogy a második világháború után hogyan alakult ki Németországban egy teljesen új nemzeti konstrukció. A korábbi évtizedek legfontosabb témái - köztüik a „Mi a német?” és „Ki a német?” kérdései - helyett egy európai identitás és egy koz mopolita szemlélet került előtérbe, s ma már egyik sem választható el a németek (ön)képétől (Banchoff, 1998). A világban így Németor szággal szemben az az elvárás, hogy az mindig kiálljon az európai értékek, a nyitott társadalom, a befogadás és az integráció mellett. A francia-német együttműködés tehát kollektív értékeket nyújt, 


\section{Külïgyi Szemle}

és segít megérteni az egymáshoz kapcsolódó identitásszerepeket. Az elmélet alapján így kijelenthető, hogy a két ország immár nem önálló nemzeti történelmet ír, hanem közös, együttes jövőt épít.

E gondolatok után kérdés, hogy a realista elmélet részéról hogyan értékelhető ez a kapcsolat. A hagyományos realista felfogás szerint a francia-német közeledés nem más, mint a nemzeti érdekek maxima lizálásának az eredménye (McCarthy, 1993). Így a kétoldalú tárgyalá sok során csak azok a területek kerülnek szóba, amelyek az önérdek szempontjából kiemelkedő jelentőséggel bírnak, és a továbbfejleszté süik az adott nemzetállam számára egyértelmű nyerô helyzetet eredményezne (Pedersen, 1998). Itt állapítandó meg, hogy a neorealista iskola gondolkodásának a középpontjában - ahogy John Mearsheimer (2014) pontosan megfogalmazta - nem más áll, mint a hatalom és az erő. Németország számára a második világháború után egyértelműen elzáródott az út a védelem, a katonai hatalom és a befolyásnak a klaszszikus értelmezés szerinti megvalósításához. Új utakat kellett találnia az erőteljes önvédelem és érdekartikuláció számára (Gordon, 1995). Ezért - a realisták szerint - az együttmúködés és az abból fakadó közös tevékenységi területek és akciók nem mások, mint a német és a francia vezetés kölcsönös stratégiai számításainak a megvalósulása.

Függetlenuil attól, hogy melyik elméleti iskolának akarunk elsóbbséget adni, a tények alapján egyértelmû: a francia-német tandem volt az elmúlt 70 évben az integráció megkérdójelezhetetlen moz gatórugója. A két ország történelmi megbékélése, a Konrad Adenau er és Charles de Gaulle által elindított szorosabb együttmúködés, az Elysée-szerződésnek megfelelően tett egyre több közös lépés, Helmut Schmidt és Giscard d'Estaing kulcsfontosságú új kezdeményezései, a közös küil- és biztonságpolitika, majd a közigazgatás egyes intézményei közötti mind mélyebb együittműködés, a Helmut Kohl és François Mitterrand által fémjelzett elmélyült kapcsolatok egyértelmúen egy évtizedeken át tartó európai vezető szerepet bizonyítanak (Ziebura, 1997; Defrance és Pfeil, 2016; Petter, 2014; Zachar, 2018).

Ez az együttmúködés alapozta meg a mai európai rendet, és nyilvánvaló, hogy Németország és Franciaország egyértelmű nyertese 
volt a változás valamennyi lépcsőfokának: a hatalom és a hegemónia minden vonatkozásában a két állam alakította és irányította az európai integrációt. Az együttmúködés révén az egyes célok - mint a gazdagság, a katonai hatalom, a kulturális vezető szerep - megerősödhettek. A mondás úgy tartja: amit Németország és Franciaország Európában eldönt, azt az EU legtöbb tagállama követi és megvalósítja. (Lásd ezzel kapcsolatban az Európai Unió Tanácsának német elnöksége által javasolt és a francia politika által támogatott, Európa jövőjéről szóló konferencia népszerúsítését [EU2020.de, 2020].) A kérdés persze, hogy ez meddig lesz érvényes. Jelenleg annyi jelenthető ki, hogy ez a tézis mindaddig biztosra vehető, amíg a nemzeti érdekek összhangban állnak az európaiakkal, és az adott szereplők számára hatalomgyarapodást jelentenek.

Különösen a jelenleg zajló európai diskurzusok fényében érdemes erre figyelniük a nemzetközi elemzőknek, hiszen már a pandémiát megelőzően egyre több jele volt a nyugat-európai államokban is a liberális világrend kritikájának. Az együttmúködés és a tolerancia helyett ismét az önkezdeményezés, az önvédelem, az egyéni problémamegoldási módok kerültek a nemzetközi napirend előterébe (Cianetti, Dawson és Hanley, 2018; Albertazzi és Vampa, 2021). Franciaország és Németország sem kivétel. A belpolitikai diskurzust mindkét államban ismét beárnyékolják ezek a kérdések (Havertz, 2021). Főleg amiatt, hogy az elmúlt évtizedben a Franciaországhoz füződô viszony egy kényelmes kártyává vált a német politikában, amely mindig jelen van, újra és újra kijátszható, de nem tartalmaz új, váratlan koncepciókat. A másik oldalon pedig a francia elnökök elsősorban az emlékezés kultúrájának megfelelően ápolták a Németországgal való kapcsolatokat, ami „örökös ünnepélyességnek" volt tekinthető, de nem léptek ki ők sem a komfortzónából (Beaune, 2020).

Elemzésem szempontjából ez azért fontos, mert arra világít rá, hogy a Németországgal fenntartott kapcsolat időnként fontosabb volt Franciaország számára, mint maga az európai projekt. Az uniós integráció nem volt más, mint a francia-német megbékélés egyfajta továbbfejlesztése egy magasabb szinten, és egy lehetőség annak 


\section{Külïgyi Szemle}

leplezésére, hogy Párizs nem táplált különösebben ambiciózus euró pai politikai célokat (Simon, 2020). Ez a helyzet az elmúlt években, Emmanuel Macron színre lépése óta egyértelmúen megváltozott. A mostanság elhangzó beszédekből és megjelenő publikációkból az látható, hogy Európa az új francia többség politikai identitásának a fontos részévé vált, ráadásul úgy tűnik, az integráció elmélyítésének és a francia-német kapcsolatoknak a kezdeményezése is francia kézbe került. E mögött egy újonnan kialakuló exception française tézise és a De Gaulle-i grandeur koncepció újjáélesztése is valószínúsíthető (Flandrin, 2021). Macron felismerte, hogy a brexit, valamint a német belpolitikai válság miatt Franciaország - a stabilitás és a biztonság fenntartása mellett - átveheti Európa vezetését, és a francia irányítású EU ismét globális politikai játékossá válhat.

\section{Francia tervek Európa megújítására}

Emmanuel Macron, aki korábban François Hollande elnök (2012 2017) gazdasági és pénzügyi tanácsadója volt, később, 2014 és 2016 között pedig gazdasági, ipari és digitálisüigyi miniszteri tisztséget viselt Manuel Valls szocialista kormányában, 2016-ban megalapította a hagyományos francia pártrendszert megújítani igyekvő La République En Marche! [Köztársaság Elöre!] nevű centrista, szociálliberális politikai alakulatot (Kempin - Tokarski, 2017). A már miniszterként is újításokat, a klasszikus szocialista politikai iránnyal gyakran szembemenô döntéseket felvállaló fiatal politikus az elnökválasztás két fordulójában egyértelműen maga mögé utasította a különböző botrányokba süllyedt hagyományos pártok és a radikális jobboldal jelöltjeit is (Duhamel, 2018). A frissen megválasztott elnök azonnal a francia állam addig elfoglalt helyzetének az újragondolását, a gazdasági és társadalmi reformot, a klímakérdést és a társadalmi integrációt he lyezte előtérbe annak érdekében, hogy az európai politikában betöltött francia pozíciók ismét erőssé válhassanak (Gazdag, 2019, 9-10. o.). Emiatt az új államfőt sokan hazája két legkiemelkedőbb személyiségéhez, De Gaulle és Mitterand elnökhöz hasonlítják. Eddig csak ők 
voltak képesek az elnöki hivatalban rejlő lehetőségeket minden tekintetben kihasználni a francia hatalmi szerep növelésére.

Miközben világszerte megerősödött a populizmus, és a hagyomá nyos politikai értékek megkérdőjeleződtek, Macron hirtelen a liberá lis demokrácia, az internacionalizmus és az institucionalizmus egyik meghatározó szószólójává, védelmezőjévé avanzsált (Tiersky, 2017), s immár évről évre ezeket az elveket hirdeti a Párizsi Békefórumon is.

Minderre többek között azért volt szüksége, mert időközben az európai vezető hatalmat - akarva-akaratlanul is - megszerzô német politikai elit súlyos válságba sodródott. A berlini integrációs politika és az európai vezető szerep mögött álló politikai erők, a nagy néppár tok súlyos krízist éltek át. A 2021-es választási eredményeket meg előzően Németország Szociáldemokrata Pártja (Sozialdemokratische Partei Deutschlands, SPD) egyik választási kudarcból a másikba bukdácsolt, alig mutatkozott jele a belső megújulásnak, és a meghatározó társadalmi vitakérdéseket sem tudta befolyásolni (Die Zeit, 2019). A Kereszténydemokrata Unió (Christlich Demokratische Union, CDU) új vezetése pedig sorra kritikát váltott ki a párt belső köreiből, és lát ványosan elveszítette a választók bizalmát, elsősorban a keletnémet tartományokban (Kappel, 2014, 341-352. o.).

Angela Merkel pragmatizmusa éppen arra épüilt, hogy mindig megfelelő belső támogatást tudjon a kormányzat mögött (Hettyey, 2018), ezért a nagy identitáskérdésekben kerülte az összecsapásokat, ám a megváltozott, átmediatizált, egyre inkább új eszmékre hangolt német közvélemény szemében eltávolodott a hagyományos pártértékektől és a klasszikus kereszténydemokrata hagyományoktól. Merkel felis merte, hogy egyre kevesebb kérdésben van meg az egész társadalmat átható konszenzus, és egyre több az eddigi utat megkérdőjelező, a bevett megoldásokat kritizáló hang. Különösen a fiatalok között, akik nek körében a nagy néppártok támogatottsága történelmi mélypontra zuhant. A közös politikai cselekvés mögül lassan elfogyott a levegő, a német nagykoalíció hajója megfeneklett (Marschall, 2019), és csak az új eszmékre való nyitottságukat mindvégig hangoztató szociáldemokratákat viszik tovább az új kormányzati hullámok. 


\section{Külïgyi Szemle}

Ilyen körüilmények között nem volt meglepő, hogy a francia elnök igyekezett átvenni a kezdeményezókészséget, és többször is az in tegráció megújítására tett javaslatot; az Európa-projekt újragondolá sához szükséges új dinamizmust - német indítványok hiányában - a francia változásokkal kívánta elérni. Macron számára hazája szuvere nitása immár elválaszthatatlan az európaitól, és azon belül a német kapcsolattól. Az olyan kihívásokat, mint a migráció, az energetika, a technikai innováció vagy a védelempolitika megújítása, Franciaország önmagában nem képes kezelni. Emellett, ahogy azt Macron jelezte, a globális versenyben az olyan óriások ellen, mint a Google vagy a Facebook, egyetlen ország sem képes a győzelemre, de európai szin ten - Németországgal egyetértésben - legalább az egységes szabá lyozásuk lehetôvé válhat (Tiersky, 2017, 92-94. o.).

Az integráció jövője kapcsán Macron elnöknek a legjelentősebb megnyilatkozása minden bizonnyal a 2017. szeptember 26-án, a Sorbonne Egyetemen tartott hosszú beszéde volt. Abban, ahogy a címe is nyilvánvalóvá tette, a „szuverén”, „egységes” és „demokratikus” Európa újraalapítását követelte. Az általa kifejtett javaslat azon a feltételezésen alapul, hogy az Európai Unió a jelenlegi formájában túl gyenge, túlságosan lassú és meglehetősen hatástalan. Ez nemcsak a közösség egésze, de a tagállamok számára is komoly gondot jelent, hiszen így nem lehet megoldani korunk nagy kihívásait, és hiányoznak az új problémák felszámolásához a közös keretek. Épp ezért együtte sen és konkrét intézkedésekkel kell két irányba is reagálni: egyrészt a globalizáció új viharaira kell válaszokat megfogalmazni, másrészt a globalizmus nyomán felerősödô nacionalizmusra, protekcionizmusra és az elszigeteltségbe forduló szuverenitáskövetelésekre is reagálnia kell az EU-nak. Ez pedig nem lehet más, mint az integráció tartalmi megújítása, további elmélyítése és újra a gyors előrehaladás irányába állítása.

Merkel - minden vita és eltérő álláspont ellenére - a kormány zásával szembeni kritikák alapján arra a felismerésre jutott, hogy a populizmus és a nemzetállamok Európájának a gondolata komoly kihívást jelent, és így veszélybe kerülhet az elért uniós eredmények 
megőrzése (Gaskarth és Oppermann, 2019). Épp ezért értékelhetjük az utolsó lépéseit egy politikai hagyaték előkészítéseként: a németfrancia kapcsolatok kétoldalú megerősítése, a közös európai ügyek szerződésbe foglalása révén megkérdőjelezhetetlen örökséget kívánt hagyni az utódaira, és ezzel - immár a hivatalosan is bejelentett utolsó kormányzati ciklusa utáni időre vonatkozóan - kijelölhette a leendő német kormányok és az európai vezetők számára az irányt. A „merkeli örökség” a bilaterális aacheni szerződés megkötésében öltött testet 2019. január 22-én. A paktum egyértelmű állásfoglalás volt a németfrancia tengely minél szorosabbra füzése, az európai egység védelme és egyben az európai folyamatok közös német-francia irányítása mellett (Krotz - Schild, 2018; Zachar, 2019).

A német politika számára Európa Adenauer kancellársága óta szimbolikus jelentőséggel bír. Az egyszerű anyagi érdekek mellett kialakult egy olyan értékközösség (Wertegemeinschaft) képe, amely szinte sehol máshol nem jelenik meg a tagállamok körében (Calliess, 2004; Mandry, 2009). Épp ezért a berlini politikai centrum számára a német érdekek szigorúan az európai keretrendszerben értelmezhetők. Ez áll annak a hátterében is, hogy a német politika nem tudja kezelni a nemzetállamok Európájával kapcsolatos újabb vitákat, a nemzeti érdekek elótérbe állítását és folyamatos hangsúlyozását, s azokat egyes országok múltba révedéseként és egy rég elhagyott zsákutcába vezető útként értelmezi. A 2008-as gazdasági válság óta azonban érzékelhe tő, hogy az unió jövőjével összefüggő nagy kérdésekben Merkel kan cellár asszony nem tett komoly lépéseket, sokkal inkább az adott aktuális kihívások rövid távú megoldását szorgalmazta, és a problémák tüneti kezelésére szorítkozott (Streeck, 2018; Hettyey, 2018). (Az ettől eltérő hangokat megüitő szociáldemokraták - így akár Sigmar Gabriel, akár Martin Schulz, akik egyaránt kihívóként jelentkeztek Merkellel szemben - eleddig rendre elvéreztek és elbuktak a választásokon.)

Ez a folyamat érzékelhető az aacheni szerződésben is, és ezért látja Macron elnök saját magát feljogosítva arra, hogy nagy ívú víziók felvázolásával tartsa napirenden az unió jövőjéről folytatott vitákat, és ezzel pozícionálja magát a nagyhatalmi politikában. Mindemellett a 


\section{Külïgyi Szemle}

felerősödő populista és nemzetállami retorika idejént Macron egyér telműen német- és Európa-barát partnernek látszik Németországból. A német EU-koncepciók nem nyernének támogatást sem Jean-Luc Mélenchon radikális baloldali, sem Marine Le Pen szélsőségesen nacionalista vagy Eric Zemmour új jobboldali politikájának a hatalomra kerülése esetén, így szinte a macroni új politika az együttműködés jövőjének az utolsó mentsvára. (A képet egyedül Valérie Pécresse előretörése árnyalhatja, amennyiben a most Les Républicains névre ke resztelt konzervatív, jobboldali, gaulle-ista politikai mozgalom jelöltje bekerïl a választás második fordulójába.)

Noha az egymásrautaltság ilyen erős, a közös nagy ívű lépések mégis kétségesek. Nem látszik, hogy a francia belpolitikát megnyugtatná és stabilizálná az új francia nagyhatalomról szóló narratíva, és úgy tűnik, a német belpolitikai stabilitás helyreállítása után az új ber lini kormány visszakövetelheti a kezdeményezés előnyét a maga szá mára, és újragondolhatja az évtizedes kényelmi politizálást. Macron határozottan menne előre az integrációt erősítő, általa kijelölt úton, és mindeközben olyan széles terüileteken kíván reformokat - a digitális gazdaságtól az intézményi megújhodásig, a határvédelemtől és a közös haderôtől a pénzpolitikai rendezésig -, hogy szinte minden egyes javaslatához tud ad hoc partnereket és lehetséges szövetségeseket felvonultatni. Ezzel is képes nyomás alá helyezni Berlint, s a meghatározó kérdésekben egyre gyorsabb reakcióra, mind határo zottabb fellépésre akarja sarkallni annak politikáját, ami az új német kormánykoalíció alapját jelentő programdokumentumból is kiderül (Mehr Fortschrilt wagen, 2021).

\section{Várható német irányok}

Az új német kabinet - az SPD, a Zöldek (Die Grünen) és a Német Sza baddemokrata Párt (Freie Demokratische Partei, FDP) - által kidolgozott koalíciós szerződés jelentős teret biztosít az Európa-politika kérdéseinek, ugyanis a francia félhez hasonlóan arra a következtetés re jutott, hogy Németország egyedül nem, csak az „európai projekten 
keresztuil" tud hatékonyan fellépni az új kihívásokkal szemben. Ezt megerősíti az a feljebb már említett hagyományos megközelítés, hogy a németek számára az uniós kérdések nem a küil-, hanem a belpolitikához tartoznak. Mint a közösség legerősebb és legnagyobb tagállamának a vezetôje, az új német kormányzat - talán reflektálva Macron elnök kulcsszavaira - a globális felelősségvállalás jegyében „egy demokratikusan szilárd, tárgyalóképes és stratégiailag szuverén unió" megvalósításáért kíván dolgozni. A dokumentum szerint Németor szág érdekeit Európáéi fényében kell meghatározni (Mehr Fortschrilt wagen, 4383-4390. sor), azonban ha e kijelentés mögé nézünk, akkor azt láthatjuk, hogy számos, a német-francia együttmúködés keretei között 2017 óta tárgyalt kérdéskört emeltek be a célok közé.

Ezek közé tartozik a Macron elnök által is rendszeresen hangoz tatott „stratégiai szuverenitás” kérdése, amely nemcsak az Európával közvetlenül határos válsággócok tekintetében, hanem globális kontextusban is jelentkezik: érinti az olyan, alapvetően tǔzvonalba került területeket, mint az energiaellátás, a nyersanyagimport és a digitális technológia, továbbá az egységes egészségügyi koncepció. Ehhez kapcsolódik, hogy a beruházások terén elsőbbséget kívánnak adni a digitális infrastruktúra, a közös vasúthálózat vagy éppen a megújulóáramés hidrogén-infrastruktúrák fejlesztésének. De ide sorolható az a törekvés is, hogy - többek között a pandémia leküzdésére - az EU egészségügyi hatósága számára megfelelő hatásköröket és forrásokat tudjanak biztosítani, s kiépüiljön egy jól működő, egységes európai egészségügyi adattér. Az aacheni szerződés szellemében erősíteni kívánják az európai katasztrófavédelmet, valamint a kritikus áruk közös beszerzését és gyártásának koordinálását. Ugyanakkor e törekvések közé tartoznak olyan, a közvélemény előtt kevésbé ismert fontos területek is, mint a szabványosítás vagy az európai Open Source 5/6G kérdésköre, és azokkal a kritikus technológiák és infrastruktúrák jobb védelme is. Vagyis az innováció hullámain egy olyan irányba fejlődhet a német-francia ipar, amely segítségével az európai célok szerint alakítható a globális menetrend. Ezek a folyamatok biztosíthatják Európa jövőbeni verseny- és tárgyalóképességének az alapjait. 


\section{Külïgyi Szemle}

Szintén a 2019-es bilaterális megállapodás jelölte ki az utat a stratégiai szuverenitástól elválaszthatatlan terület, a közös védelem és biztonság terén. E tekintetben az új német kabinet tervei egybecsengenek a Macron elnök által az európai képességek növeléséről felvázoltakkal: a közös kül- és biztonságpolitikában be kívánják vezetni a minősített többségi döntéshozatali eljárást, politikai célként fogalmazták meg egy olyan átfogó biztonságfogalom meghatározását, amely erősitheti a német-francia bilaterális dokumentumban is kiemelt civil krízisprevenció és krízismenedzsment eszköztárát. Szintén a megerősített együittmúködés irányába kívánnak elmozdulni a fegyvergyártás, a fegyverkezés, a kiképzés és a missziók terén.

A migrációs kihívások tekintetében Macron már 2017-ben világosan fogalmazott: „Vagy bezárjuk magunkat a határaink mögé, ami nemcsak illuzórikus, de egyben hatástalan is lenne, vagy közös fellépést teremtünk a határkérdések, a menedékjog és a bevándorlás terén." Ennek elősegítése a francia tervek szerint egy európai me nekültügyi hatóság felállításával történhetne, amely az eljárások fel gyorsítása és szabványosítása terén lenne aktív. Közös európai ha tárvédelmi kapacitásokra van szükség, továbbá az egyes államoknak a menekültek jobb befogadását és elosztását kellene biztosítaniuk, és az itt maradó meneküiltek számára megfelelő oktatási és integrációs programokat létrehozniuk (Zachar, 2019, 93-99. o.). E kérdések az új német kormány programjában is elôkerülnek, és ugyanebbe az egyértelmú irányba mutatnak: a Frontex valódi határvédelmi szervvé történő megerősítése, a központi elosztással megvalósuló közös uniós menekültrendszer és az integráció jelenti a fô pilléreket (Mehr Fortschritt wagen, 2021, 4744-4809. sor).

Noha az aacheni szerződésben nem szerepelt, az új német ka binet az Európa jövőjéről megkezdett konferenciát az EU megrefor málására kívánja felhasználni, ami akár az alapszerződések módosításához is elvezethet. Immár a német politikai elit is egyértelmúen állást foglal a Macron elnök által felvetett javaslatok közüil az Európai Parlament tagjai megválasztása során alkalmazandó közös európai választójog bevezetése és a transznacionális választási listák mellett, 
és ki szeretnék terjeszteni a jogszabály-kezdeményezés jogát az EPre is. Ezekhez csatlakozhat még a jogállamisági kérdések határozott újragondolása, ami egyben az Európai Unió Bíróságának az erősítését is magával vonhatja.

Érdemes még egy kérdéskört kiemelni, ez pedig a gazdasági és monetáris unió, valamint a költségvetési politika keretrendszere és jövője. Itt a német-francia javaslatok rendkívül komoly újítást eredményeztek az elmúlt másfél évben. Az egyuittmúködés legfontosabb és legújabb pontja egyértelmúen a járvány utáni újjáépítési csomag lett. Ezt tekinthetjük az új európai vezetés első jelének is. Macron elnök kezdeményezésére ugyanis három hónappal az európai járvány kitörése után a két ország vezetése egy meglepő újjáépítési tervet javasolt (Ministère de l'Europe el des affaires élrangères, 2020). A sokak által csak „Merkron-tervként” emlegetett megoldással a közösség immár hitelt vehet fel a pénzpiacokon az újjáépítési alap feltöltésére (European Commission, 2020), amelyet ideiglenes helyreállítási eszköznek tekintenek ugyan, de a hatása állandóvá válhat. Ez azért is figyelemre méltó, mert Németország és Franciaország a 2008-as válság idején eltérő nézeteket vallott a gazdaságról. Berlin nemesak az európai szerződések, hanem - a német gazdasági szabályozás európai szintre való áthelyezésével - az erős euró ôrzője is volt. Párizs ezzel szemben a beavatkozó állam modelljét akarta megvalósítani, amely a válságok idején többször is támogatást és finanszírozást ajánlhat fel.

Az új gazdasági együittműködésről szóló vitákban újra és újra fel bukkantak az annak támogatói és ellenzôi közötti törésvonalak. Az ellenzőkre (Ausztriára, Finnországra, Hollandiára és Dániára) a sajtóban többször is "fukar négyekként” hivatkoztak. Franciaország és Németország kompromisszumokra törekedett a szüikséges pénzösz szeg nagyságát, annak előteremtési módját (a pénzügyi piacokon vagy adókon keresztuil szerezzék-e meg), valamint a felhasználás mikéntjét illetően (támogatások vagy kölcsönök formájában történjen-e). Éppen a „gazdag” és „szegény”, az „északi” és „déli” tagállamok közötti, évtizedekre visszanyúló, régóta húzódó vita, illetve az euró „felpuhulásával” kapcsolatos, eddig a németek által is osztott félelmek miatt volt különösen forradalmi a két ország közös fellépése (Maurice, 2020). 


\section{Külïgyi Szemle}

Valószinúleg szándékos politikai lépés volt Macron részéról is, amikor Ursula von der Leyen megválasztását szorgalmazta az Európai Bizottság $(\mathrm{EB})$ elnöki posztjára. Ezzel a francia elnök bizonyára új támogatót akart nyerni az európai céljai és a francia-német megállapodások számára. Hogy ez sikerült is, az mutatja, hogy a gazdaságélénkítő csomag előterjesztésekor az EB szóról szóra átvette a francia-német javaslatot, és csak néhány kiegészitést tett hozzá ( $\mathrm{Si}$ mon, 2020). Az elhangzott tervek alapján egyértelmû: a Stabilitási és Növekedési Paktum jelenlegi rugalmasságának a bázisán a válság után is meg kívánják tartani az EU hitelfelvételi képességét. Ezzel viszont az EB már önálló szereplővé válik a tőkepiacon, a közösen vállalt és behajtható adóssággal, valamint a Brüisszelből érkező pénzügyi támogatással az európai központ és a nemzetállamok közötti erőviszonyok egyértelmủen eltolódnak (Mehr Fortschritt wagen, 2021. 4469-4489. sor). A pénzügyi változások nyomán ugyanis erősödhet az Európai Csalás Elleni Hivatal (OLAF), az Európai Ügyészség (EPPO) és az Európai Számvevőszék (ECA) szerepe is.

\section{Konklúziók}

A fentiek alapján talán elmondhatjuk, hogy az utóbbi hónapok fejleményei egy irányba mutatnak: az aacheni szerződésben kijelölt merkeli örökség továbbra is egybevág a francia politika jelenlegi elképzeléseivel és önértékelésével. A közelgő francia választások fényében is kijelenthető, hogy a nagyhatalmi státusz - a „kemény tényezőkön” túl - új, látványos, víziószerủ narratívákkal is kivívható, ha azok mögé az európai tömegeket fel lehet sorakoztatni.

Macron elnök egy dinamikus, vállalkozó szellemű Franciaországot lát maga előtt, amely a nemzeti gondolatot abban leli meg, hogy az Európai Unió vezérnemzetévé válik, és így azt a multipoláris világrend egyik megkerülhetetlen és kimagasló gazdasági-szellemi hatalmává emeli (Tiersky, 2017, 88-89. o.). Egyértelmú, hogy a francia hatalmi ambíciókkal összefüggő államreform és az európai közösség megreformálása Macron elnök számára egyazon érme két oldalát jelenti. Meggyőződése, hogy a mélyülő európai integráció a francia nemzeti 
érdekeket is szolgálja, hiszen számos alapvető kihívás már csak közösségi szinten kezelhető. Ehhez a liberális témakörök nagy részét is hasznosítja: a demokrácia, a piacgazdaság, a jogállamiság és a felvilágosodásban gyökerező technológiai optimizmus mind elengedhetetlen az EU sikere szempontjából. Ezt egészíti ki a De Gaulle-féle grandeur és a Mitterrand idejéból ismert, francia vezetésú Európa helyreállításának a víziója, amely a civilizatorikus öntudat legmagasabb szintjét jelöli ki, és egyben pragmatikus ellenpólust jelent a francia radikális jobboldal nacionalista, EU-kritikus és antiliberális programjával szemben (Gheciu, 2019). Macron mindezzel nemcsak a pragmatista programját tudja népszerúsíteni, de egyben kiveheti a radikális jobboldal kezéból Franciaország „naggyá tételének” a programját is. (Donald Trump elnök nyomán Le Pen többször is használta a „Make France great again” frázist [The Times, 2017].)

Macron terve más előjelekkel és más szándékokkal, de találkozik az új német politikai vezetés Európa-politikájával, amely a kiadott kor mányprogramban egyértelmúen állást foglalt a föderatív elmozdulás mellett. Ahogy a történelmi Elysée-szerződés esetében teljesen más prekoncepciók vezették a feleket a megegyezés és az együttmúködés erősítése felé, úgy a különböző utak most is egy irányba konvergálnak, és az európai központi szint erósítését vetítik előre.

Visszatérve a kiinduló gondolatunkhoz, jól látható, hogy a realista felfogás szerint a német-francia javaslatok és együttműködés mindkét ország számára pozícióemelkedést, az európai központnak pedig hatalomgyarapodást hoznak. A liberális elmélet hívei számára viszont egyértelmű: „Európát” is a politikusok elképzelései hozzák létre, és új nemzetek feletti konstrukcióként új cselekvési területekre irányítják azt.

\section{Irodalomjegyzék}

Albertazzi, Daniele és Vampa, Davide (szerk.) (2021). Populism and New Patlerns of Political Competilion in Western Europe. London: Routledge. Auswärliges Amı (2020). How Germany Is Helping Europe in the Covid-19

Crisis. A letöltés ideje: 2021. február 12. https:/www.auswaertiges-amt. de/en/aussenpolitik/europe/maas-corona-europe/2328352. 


\section{Külïgyi Szemle}

Balázs Gábor (2009). Egy francia jelenség: a gaulle-izmus. Beszéló, 14(5), $18-36$.

Banchoff, Thomas (1998). Germany's European Policy: A Constructivist Perspective. CES Germany \& Europe Working Papers, No. 08.1. University of Pillsburgh. A letöltés ideje: 2021. január 10. http://aei.pitt. edu/63650/.

Beaune, Clément (2020): L'Europe, par-delà le COVID-19. In: Politique élrangère, 85(3), 9-29. A letöltés ideje: 2021. április 11. www.ifri.org/ fr/publications/politique-etrangere/articles-de-politique-etrangere/ leurope-dela-covid-19.

Bremner, Charles (2017). Only I Can Make France Great Again, Says Le Pen. The Times. Aletöltés dátuma: 2021. február 15. https:/www.thetimes.co.uk/ article/only-i-can-make-france-great-again-savs-le-pen-Ogrpnbhh9.

Calliess, Christian (2004). Europa als Wertegemeinschaft - Integration und Identität durch europäisches Verfassungsrecht? JuristenZeilung, 59(21), 1033-1045.

Cianetti, Licia, Dawson, James és Hanley, Sean (2018). Rethinking "Democratic Backsliding" in Central and Eastern Europe. Looking Beyond Hungary and Poland. East European Politics, 34(3), 243-256. A letöltés ideje: 2022. január 17. https://doi.org/10.1080/21599165.2018 .1491401.

Cole, Alistair Mark (2001). Franco-German Relations. Political Dynamics of the EU. Harlow: Longman.

Defrance, Corine és Pfeil, Ulrich (szerk.) (2016). Der Élysée-Vertrag und die deulsch-französischen Beziehungen 1945 - 1963 - 2003. Berlin, Boston: Oldenbourg Wissenschaftsverlag.

Die Zeil (2019). Früher haben Sie SPD gewählt - warum heute nicht mehr? A letöltés ideje: 2021. február 12. https://www.zeit.de/politik/2019-05/ sozialdemokraten-spd-wahlergebnisse-absturz-waehler.

Diószegi István (1994). A hatalmi politika másfél évszázada. Budapest: Magyar Tudományos Akadémia.

Duhamel, Olivier (2018). Macron ou l'illusion de la république gaullienne. Pouvoirs, 166(3), 5-12. A letöltés ideje: 2021. november 15. https://www. cairn.info/revue-pouvoirs-2018-3-page-5.htm.

Dungan, Nicholas (2019). The New Treaty of Aachen: More Than Just A Symbol? Allanlic Council. A letöltés ideje: 2021. március 11. https://www. atlanticcouncil.org/blogs/new-atlanticist/france-germany-treaty-ofaachen/. 
EU2020.de (2020). Promoting A Vibrant Civil Society and Social Cohesion. A letöltés ideje: 2021. április 11. https://www.eu2020.de/eu2020-en/ civil-society-conferende-on-the-future-of-europe/2360192.

Euractive (2019). Macron Proposes Replacement Commissioner Candidate. Euractiv. A letöltés ideje: 2020. november 28. https://www.euractiv. $\mathrm{com} / \mathrm{section} /$ future-eu/news/macron-proposes-replacementcommissioner-candidate.

European Commission (2020). Recovery and Resilience Facility. A letöltés ideje: 2021. április 22. https://ec.europa.eu/info/business-economveuro/recoverv-coronavirus/recoverv-and-resilience-facility en.

Fehér Zoltán (2020). Realpolitik \& Cooperation in the Age of COVID-19. How Can the World Escape Captivity? Global Securily Review. A letöltés ideje: 2020. november 21. https://globalsecurityreview.com/realpolitikcooperation-covid-19/.

Flandrin, Antoine (2021). Le général de Gaulle, grand inspirateur d’Emmanuel Macron. Le Monde. A letöltés ideje: 2021. április 13. https:// www.lemonde.fr/idees/article/2021/01/08/le-general-de-gaulle-grandinspirateur-d-emmanuel-macron_6065561 3232.html.

Fukuyama, Francis (1989). The End of History? The National Interest, 16, 3-18.

Fukuyama, Francis (2018). Identity - The Demand for Dignity and the Politics of Resentment. New York: Farrar, Straus \& Giroux.

Gaskarth, Jamie és Oppermann, Kai (2019). Clashing Traditions: German Foreign Policy in a New Era. International Studies Perspectives, A letöltés ideje: 2021. november 20. https://academic.oup.com/isp/advancearticle/doi/10.1093/isp/ekzO17/5581524.

Gazdag Ferenc (2019). Milyen hatalom Franciaország a 21. század elején? In Gazdag Ferenc (szerk.), Franciaország a 21. század elején (9-42. o.).

Gheciu, Alexandra (2019). Remembering France's Glory, Securing Europe in the Age of Trump. European Journal of International Security, 4(3), 1-20. Gordon, Philip H. (1995). France, Germany and the Western Alliance. Oxford: Westview Press.

Haas, Ernst B. (1964). Beyond the Nation State. Functionalism and International Organization. Stanford: Stanford University Press.

Havertz, Ralf (2021). Radical Right Populism in Germany. AfD, Pegida, and the Identilarian Movement. London: Routledge.

Hettyey András (2018). Merkel után, AKK előtt: A CDU útkeresése. SVKK Nézópontok, (4). 1-6. 


\section{Külïgyi Szemle}

Kappel Robert (2014). Global Power Shifts and Germany's New Foreign Policy Agenda. Strategic Analysis, 38(3), 341-352.

Kempin, Ronja és Tokarski, Pawel (2017). Frankreich „in Bewegung”: Präsident Emmanuel Macron - Hoffnungsträger und schwieriger Partner für Deutschland. SWP-Akluell, 34. A letöltés ideje: 2021. január 21. https:// www.ssoar.info/ssoar/handle/document/52136.

Krotz, Ulrich és Schild, Joachim (2018). Back to the Future? Franco-German Bilateralism in Europe's Post-Brexit Union. Journal of European Public Policy, 25(8), 1174-1193.

Lay, Franziska és Nix, Sebastian (szerk.) (2007). Erbfeinde - Erbfreunde. Die deulsch-französischen Beziehungen zwischen 1870 und $1945 \mathrm{im}$ Spiegel zeilgenössischer Lileratur. Eine Ausslellung des Deulsch-Französischen Instiluts. Ludwigsburg: Deutsch-Französisches Institut.

Mandry, Christof (2009). Europa als Werlegemeinschafl: Eine theologisch ethische Studie zum politischen Selbstverständnis der Europäischen Union. Baden-Baden: Nomos.

Marschall, Christoph von (2019). Krise in SPD und Union - Deutschland braucht schnell eine neue Regierung. Der Tagesspiegel, A letöltés ideje: 2021. november 15. https://www.tagesspiegel.de/politik/ krise-in-spd-und-union-deutschland-braucht-schnell-eine-neueregierung/24414200.html.

Maurice, Paul (2020). Coronavirus - la solidarité franco-allemande à l'épreuve. Editoriaux de l'Ifri, A letöltés ideje: 2021. november 15. https:// www.ifri.org/sites/default/files/atoms/files/coronavirus_solidarite_ franco allemande maurice_2020.pdf.

McCarthy, Patrick (szerk.) (1993). France-Germany, 1983-1993: The Struggle to Cooperate. Basingstoke: Macmillan.

Mearsheimer, John J. (2014). The Tragedy of Great Power Politics. Updated edition. New York: W. W. Norton \& Company.

Mehr Forlschrill wagen (2021). Bündnis für Freiheit, Gerechtigkeit und Nachhaltigkeit. Koalitionsvertrag 2021-2025 zwischen der Sozialdemokratischen Partei Deutschlands (SPD), BÜNDNIS 90 DIE GRÜNEN und den Freien Demokraten (FDP). A letöltés ideje: 2021. november 28. https://vnamic.faz.net/download/2021/ Koalitionsvertrag2021-2025.pdf.

Ministère de l'Europe el des affaires étrangères (2020). European Union - French-German Initiative for the European Recovery from the Coronavirus Crisis (Paris, 18 May 2020). A letöltés ideje: 2021. február 15. 
https:/www.diplomatie.gouv.fr/en/coming-to-france/coronavirus-advicefor-foreign-nationals-in-france/coronavirus-statements/article/europeanunion-french-german-initiative-for-the-european-recovery-from-the.

Nourry, Chrystelle (2012). Political Legitimation of the Union: the Core of Franco-German Relationship. LEurope en Formation. 366(4), 85-100. A letöltés ideje: 2022. január 18. https://doi.org/10.3917/eufor.366.0085. Pedersen, Thomas (1998). Germany, France and the Inlegration of Europe: A Realist Interpretation. London: Pinter.

Petter, Dirk (2014). Auf dem Weg zur Normaliläl: Konflikı und Versländigung in den deulsch-französischen Beziehungen der 1970 er Jahre. Oldenbourg: De Gruyter.

Rieker, Pernille (2017). French Foreign Policy in a Changing World. Practising Grandeur. London: Palgrave Macmillan.

Robinson, William I. (2011). Globalization and the Sociology of Immanuel Wallerstein: A Critical Appraisal. International Sociology, 26(6), 723-745. A letöltés ideje: 2022. január 18. https://doi. org $/ 10.1177 / 0268580910393372$.

Rosamond, Ben (2000). Theories of European Union Integration. Basingstoke: Macmillan.

Simon, Edouard (2020): Die deutsch-französischen Beziehungen. Eine Wiederbelebung in schwierigen Zeiten. Paris: Friedrisch Ebert Stiftung. Streeck, Wolfgang (2018). Europe Under Merkel IV: Balance of Impotence. American Affairs, 2(2), 162-192.

Tiersky, Ronald (2017). Macron's World. How the New President Is Remaking France. Foreign Affairs, 97(1), 87-96.

Waltz, Kenneth N. (2010). Theory of International Politics. Long Grove: Waveland Press Inc.

Webber, Douglas (szerk.) (1999). The Franco-German relationship in the European Union. London: Routledge.

Zachar Péter Krisztián (2018). From "Grandeur" to "Sécurité" and "a Special Relationship". Prague Papers on the History of International Relations, (2), 112-135.

Zachar Péter Krisztián (2019). A Macron-faktor: új lendület az európai integrá ció elmélyítésére. In Fenyvesi Ottó (szerk.), Történelludomány - Müvészel Pedagógia. Köszöntö kölel Szabó Péler, a Kodolányi János Egyelem reklora liszleletére a hatvanadik születésnapja alkalmából (91-100. o.).

Ziebura, Gilbert (1997). Die deulsch-französischen Beziehungen seil 1945. Mythen und Realitäten. Überarbeitete und aktualisierte Neuausgabe. Stuttgart: Neske, Klett-Cotta. 